\title{
EFFECTS OF KOJIC ACID ON THYROIDAL FUNCTIONS IN RATS BY SINGLE-DOSE ADMINISTRATION AND IN CULTURED RAT THYROID CELLS (FRTL-5 CELLS)
}

\author{
Yoshitaka HIGA $^{1}$, Atsushi OHKUBO ${ }^{1}$, Shunichi KITAJIMA ${ }^{2}$, \\ Matuko MORIYASU ${ }^{2}$ and Kimio KARIYA ${ }^{3}$ \\ ${ }^{1}$ Sansho Seiyaku Co., Ltd., \\ 2-26-7 Ohike, Ohnojo, Fukuoka 816-8550, Japan \\ ${ }^{2}$ Panapharm Laboratories Co., Ltd., \\ 1285 Kurisaki, Uto, Kumamoto 869-0425, Japan \\ ${ }^{3}$ Kobe Gakuin University Faculty of Pharmaceutical Sciences, \\ Arise 518 Ikawadani, Nishi-ku, Kobe, Hyogo 651-2180, Japan
}

(Received November 1, 2001; Accepted July 31, 2002)

\begin{abstract}
The effects of kojic acid (KA) on thyroidal function were studied by single-dose administration in rats and in cultured rat thyroid cells (FRTL-5 cells). In rats receiving a single dose of 1,000 $\mathrm{mg} / \mathrm{kg} \mathrm{KA}$ orally, the ${ }^{125} \mathrm{I}$ uptake from blood into the thyroid gland was significantly lower than that of the control group from $30 \mathrm{~min}$ to $24 \mathrm{hr}$ after administration. The ${ }^{125} \mathrm{I}$ organification activity of the KA groups was significantly lower than control from $30 \mathrm{~min}$ to $6 \mathrm{hr}$ after administration. However, the ${ }^{125} \mathrm{I}$ organification activity at $24 \mathrm{hr}$ or $48 \mathrm{hr}$ after administration recovered enough to be nearly comparable with the control group. In the study in FRTL-5 cells, KA inhibited iodine organification dose-dependently, but did not inhibit iodine uptake. These results suggest that the observed lower iodine uptake activity in the single-dose administration study in rats was due to the inhibition of iodine organification caused by the oral administration of KA, consequently decreasing iodine in the entire thyroid gland.

Although serum T4 showed a tendency to decrease from $2 \mathrm{hr}$ to $48 \mathrm{hr}$ after administration of KA, serum TSH did not show any evident change associated with KA in the single-dose administration study in rats. Based on these results, it is presumed that a massive dose or long administration period might be needed to decrease serum T4 and increase serum TSH.

From these results, it is presumed that KA affected thyroidal function when given at a massive dose or in a long administration period by inhibiting iodine organification in the thyroid.
\end{abstract}

KEY WORDS: Kojic acid, Thyroid function, Single-dose administration, Cultured rat thyroid cells (FRTL-5 cells), Iodine uptake, Iodine organification

\section{INTRODUCTION}

Kojic acid [5-hydroxy-2- (hydroxymethyl)-4pyrone] is known to suppress the biosynthesis of melanin at melanocytes in epidermal skin by inhibiting the activity of tyrosinase, which is an enzyme involved in biosynthesis of melanin (Nakayama et al., 1982; Higa, 1983). Based on this effect, the compound has been used as an active skin-whitening agent in the fields of cosmetics and quasi-drugs (Ohyama et al., 1990). In addition, KA is employed as a food additive to prevent enzymatic browning of fresh food products such as lobsters, crabs, vegetables, and meat (Uchino, 1986a, 1986b). Recently, Burdock et al. (2001) have reviewed the health aspects of KA in food and concluded that KA consumed in an amount and in a manner consistent with historical use did not present a safety concern (Burdock et al., 2001). 
As for the effect of KA on the thyroid gland, it was reported that the dietary administration of KA significantly decreased the levels of serum T3 and T4, while significantly increasing the serum TSH level and thyroid weights, and inhibiting iodine uptake and iodine organification in several studies (Hirose et al., 2001; Tamura et al., 1999; Fujimoto et al., 1999). Recently, we have also reported thyroid weight gain and a morphological change, i.e., follicular epithelial hypertrophy, observed in the thyroid of rats orally administered KA for 4 weeks (Higa et al., 2000). In addition, increased ${ }^{125} \mathrm{I}$ uptake from blood into the thyroid was observed along with increased ${ }^{125} \mathrm{I}$ in the TCA-precipitation fraction in the thyroid gland. However, no apparent changes were seen in ${ }^{125}$ I organification activity in the thyroid gland. As for determination of serum hormone concentration, T4 showed a decrease while TSH did not show any apparent change. These observations suggest that massive administration of KA may decrease blood T4 concentration and may enhance thyroid function compensatingly. However, the mechanism of T4 decline has yet to be clarified, since the effect of thyroid hypertrophy was too dominant. We therefore focused on a further review of the effect of KA on thyroidal functions in rats by single-dose administration and in cultured rat thyroid cells (FRTL-5 cells) in the present study.

\section{MATERIALS AND METHODS}

\section{In vivo single-dose administration study in rats}

1. Test compound, animals and housing conditions

The structural formula of KA is shown in Fig.1. KA was obtained by a fermenting method using a mutant strain of Aspergillus sp. owned by Sansho Seiyaku Co., Ltd. (Fukuoka, Japan).

Male F344/Du Crj rats, five-weeks-old, were purchased from Charles River Japan, Inc., (Kanagawa,

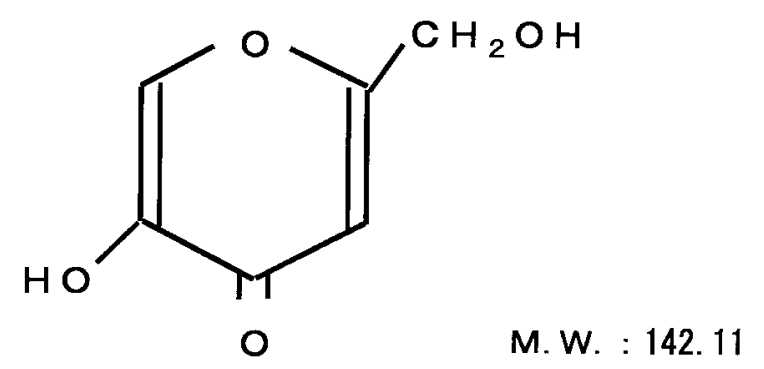

Fig. 1. Chemical structure of kojic acid (KA). 5-Hydroxy-2- (hydroxymethyl)-4-pyrone.
Japan), and were used for the experiment after 6-day acclimatization. The animal facility was air-conditioned at $24 \pm 2^{\circ} \mathrm{C}$ with a relative humidity of $55 \pm 10 \%$, and 12 light $/ 12$ dark cycle. Pellet food (MF, Oriental Yeast Co., Chiba, Japan) and tap water with sodium hypochlorite added were provided ad libitum.

\section{Administration}

Since KA influenced thyroidal function at 1,000 $\mathrm{mg} / \mathrm{kg}$ dose in our previous repeat oral administration study for 4 weeks (Higa et al., 2000), we selected $1,000 \mathrm{mg} / \mathrm{kg}$ as the dose level in the present study. Rats were given single-dose administration of KA suspended in $0.5 \%$ carboxymethylcellulose (Wako Pure Chemical Industries Ltd., Inc., Osaka, Japan) solution orally through a plastic gastric tube.

\section{General observation}

The clinical signs and mortality of the animals were checked after KA administration. Body weight was measured after administration and at autopsy. Relative thyroid weight was calculated from the measured thyroid and body weight of all animals at autopsy.

\section{Determination of thyroid ${ }^{125}$ I uptake and organi- fication}

A group of rats was promptly given $8 \times 10^{6} \mathrm{cpm} /$ $0.4 \mathrm{~mL}$ of $\mathrm{Na}^{125} \mathrm{I}(450 \sim 500 \mathrm{MBq} / \mu \mathrm{g}$, NEN Life Science Products Inc., Tokyo, Japan) saline intraperitoneally after KA administration. The animals were killed at $0.5,1,2,4,6$, and $24 \mathrm{hr}$ after injection of $\mathrm{Na}$ ${ }^{125} \mathrm{I}$ and blood samples collected. The thyroid gland was then removed and weighed for record. Four animals were used at each time point.

Another group of rats was given $\mathrm{Na}^{125} \mathrm{I}$ at $24 \mathrm{hr}$ or $48 \mathrm{hr}$ after KA administration and killed $24 \mathrm{hr}$ later. The animals were then treated in the same manner as the former group.

The radioactivity in the serum collected and in the thyroid we removed was measured by gamma counter (Auto Gamma Counting System MINAXI 5530; Packard Instrument Co., Meriden, USA).

A thyroid gland with $0.5 \mathrm{~mL}$ of cold $0.15 \mathrm{M}$ NaCl-1 mM KI added was homogenized by cooling with ice. The radioactivity of the $0.1 \mathrm{~mL}$ homogenates was then measured. The amount of proteins contained in the homogenate fraction was determined by the Lowry method (Lowry et al., 1951) using bovine serum albumin (Sigma Chemical Co., St. Louis, USA) as the standard substance. The equivalence of $10 \%$ trichloro acetic acid (TCA, Wako Pure Chemical 
Effects of Kojic acid on thyroidal functions in rats.

Industries Ltd., Inc., Osaka, Japan) was added to the remaining homogenate before centrifugation $(1,300$ $\times \mathrm{g}, 10 \mathrm{~min}$ ). After adding 5\%TCA for re-suspension, the pellet was centrifuged again to determine its radioactivity.

${ }^{125}$ I uptake ratio and TPB (Thyroid Protein Binding) were calculated as indices of the ${ }^{125} \mathrm{I}$ uptake and ${ }^{125}$ I organification activities, respectively. They were calculated by the following formula:

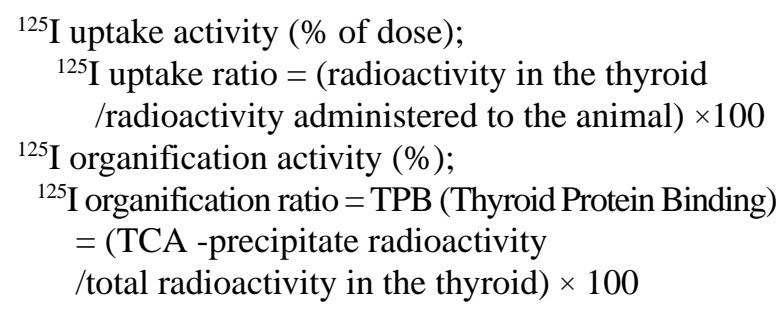

\section{Determination of serum hormone concentrations}

The hormone concentrations in the serum collected at $0.5,1,2,4,6,24$, and $48 \mathrm{hr}$ after a single dose of $1,000 \mathrm{mg} / \mathrm{kg} \mathrm{KA}$ or in the reaction medium were determined. Four animals were used at each time point.

The concentrations of serum $\mathrm{T} 3$ and $\mathrm{T} 4$ were measured with the RIA tube solid phase assay (Diagnostic Products Corporation, Los Angeles, USA), and serum TSH was measured with RIA double antibody assay (Amersham, Buckinghamshire, UK).

\section{In vitro study with FRTL-5 cells \\ 1. Cultured cells and culture conditions}

We selected cultured rat thyroid cells (FRTL-5 cells), which are used widely to analyze the mechanism of iodine transportation (Weiss et al., 1984; Brown et al., 1986) in the present study. FRTL-5 cells, obtained from the American Type Culture Collection, were cultured in Ham's F-12 medium (Gibco BRL Co., Rockville, USA) under $5 \% \mathrm{CO}_{2}$ in the air, at $37^{\circ} \mathrm{C}$, adding the following substances: $5 \%$ calf serum (Gibco BRL Co., Rockville, USA); 10 mU/mL TSH (bovine origin, Sigma Chemical Co., St. Louis, USA); $10 \mu \mathrm{g} / \mathrm{mL}$ insulin (bovine origin, Sigma Chemical Co., St. Louis, USA); $10 \mathrm{nM}$ hydrocortisone (Sigma Chemical Co., St. Louis, USA); $5 \mu \mathrm{g} / \mathrm{mL}$ apotransferrin (human origin, Sigma Chemical Co., St. Louis, USA); $10 \mathrm{ng} / \mathrm{mL}$ glycyl-L-hisdiyl-L-lysine acetate (Sigma Chemical Co., St. Louis, USA); and $10 \mathrm{ng} / \mathrm{mL}$ somatostatin (Sigma Chemical Co., St. Louis, USA) (Ambesi-Impiombato et al., 1980; Valente et al., 1983; Brown et al., 1986; Chiovato et al., 1994; Stuart et al., 1984). As a cell-dispersed solution (CTC solution),
HBSS (-) containing $20 \mathrm{U} / \mathrm{mL}$ collagenase (Wako Pure Chemical Industries Ltd., Inc., Osaka, Japan), 0.75 mg/ $\mathrm{mL}$ trypsin (Sigma Chemical Co., St. Louis, USA), 2 mM EGTA (Dojindo Laboratories, Kumamoto, Japan), and 2\% heated chicken serum (Gibco BRL Co., Rockville, USA) was employed. Both KA and the positive control were dissolved in the reaction medium in which the concentration of the culture medium, calf serum, was lowered to $0.5 \%$.

\section{Determination of ${ }^{125} I$ uptake activity}

The reaction medium was used to determine ${ }^{125} \mathrm{I}$ uptake activity and ${ }^{125}$ I organification in FRTL-5 cells. FRTL-5 cells harvested by using CTC solution were seeded onto a 24-well plate and served for study when the cells became nearly confluent. After removing the culture solution in the wells and washing with Ham's F-12 medium, $300 \mu \mathrm{l} /$ well of $5 \mathrm{mM}$ methimazole, $100 \mu \mathrm{l} /$ well of KA solution at each concentration and $100 \mu \mathrm{l} /$ well of the reaction medium containing $1 \mu \mathrm{M}$ of non-radioactive NaI (Wako Pure Chemical Industries Ltd., Inc., Osaka, Japan), including approximately $2 \times 10^{7} \mathrm{cpm} / \mathrm{mL}$ of $\mathrm{Na}$ ${ }^{125} \mathrm{I}$, were added and cultured at $37^{\circ} \mathrm{C}$ for $2 \mathrm{hr}$. Sodium perchlorate was selected as the positive control $(n=4)$ (Weiss et al., 1984) . After a two-hour incubation, the reaction was terminated by adding $50 \mu \mathrm{l} /$ well of $1 \mathrm{mM}$ NaI. The cells were washed with HBSS (+)(Gibco BRL Co., Rockville, USA) sufficiently cooled with ice and dissolved with $0.1 \mathrm{M} \mathrm{NaOH}$ to determine radioactivity by gamma counter (MINAXI 5530 Gamma Counting System; Packard Instrument Co., Meriden, USA). Cells without incubation were set as a blank.

\section{Determination of ${ }^{125} I$ organification activity}

After removing the culture solution in which FRTL-5 cells became confluent, the wells were washed with Ham's F-12 medium, with $100 \mu \mathrm{l} /$ well of KA added at each concentration or $100 \mu \mathrm{l} /$ well of the reaction medium containing $\mathrm{Na}^{125} \mathrm{I}$ (about $2 \times 10^{7} \mathrm{cpm} / \mathrm{mL}$ ), and were cultured at $37^{\circ} \mathrm{C}$ for $2 \mathrm{hr}$. Methimazole was selected as a positive control (Brown et al., 1986)(n= 4). After a two-hour incubation, $50 \mu \mathrm{l} /$ well of $1 \mathrm{M}$ $\mathrm{NaOH}$ and an equivalence of $1 \mathrm{mM} \mathrm{NaI}$ (nonradioactive) were added, followed by $1 \mathrm{~mL}$ of $10 \%$ trichloroacetic acid (TCA) to precipitate the proteins. After washing with $10 \%$ TCA, the radioactivity of the precipitates was determined. As the blank control, the cell in which $\mathrm{Na}^{125} \mathrm{I}, \mathrm{NaOH}$ and $\mathrm{NaI}$ were added after twohour incubation was used.

Both activities (\%) of ${ }^{125}$ I uptake and ${ }^{125}$ I organification were calculated from the mean value $(\mathrm{Ci})$ of 
each concentration's counts $(\mathrm{cpm})(\mathrm{n}=4)$, the mean $\mathrm{cpm}(\mathrm{Co})$ of the negative control in which the reaction medium was added instead of KA, and the mean cpm (CB) of the blank by the following formula:

${ }^{125} \mathrm{I}$ uptake activity $(\%)=(\mathrm{Ci}-\mathrm{CB}) /(\mathrm{Co}-\mathrm{CB}) \times 100$

${ }^{125} \mathrm{I}$ organification activity $(\%)=(\mathrm{Ci}-\mathrm{CB}) /(\mathrm{Co}-\mathrm{CB}) \times 100$

\section{Statistical analysis}

Student's $t$-test (Yoshimura, 1987) was applied for comparison with the control group at the $\mathrm{p}$ value of 0.05 or 0.01 in all cases.

\section{RESULTS}

\section{In vivo single-dose administration study in rats \\ 1. General observation}

Although almost all of the rats showed hypoactivity $1 \mathrm{hr}$ after receiving a single dose of $1,000 \mathrm{mg} / \mathrm{kg} \mathrm{KA}$, they recovered in about $30 \mathrm{~min}$. With respect to body weight as well as absolute and relative thyroid weights, no differences were found with the controls until $72 \mathrm{hr}$ after administration, when the observation time was over.

\section{2. ${ }^{125}$ I uptake activity}

The ${ }^{125}$ I uptake activity into the thyroid (\% of dose) of the control group increased time-dependently and remained at a constant level from $6 \mathrm{hr}$ to $24 \mathrm{hr}$ after administration. In contrast, the activity of the KA group was significantly lower than the control group from $30 \mathrm{~min}$ to $24 \mathrm{hr}$ after administration (Fig. 2).

The ${ }^{125}$ I uptake activity at $24 \mathrm{hr}$ after injection of $\mathrm{Na}{ }^{125} \mathrm{I}$, following KA administration $48 \mathrm{hr}$ before, recovered enough to be nearly comparable with that of the control at $24 \mathrm{hr}$ after KA administration (Fig.3).

\section{3. ${ }^{125}$ I organification activity}

As shown in Fig.4, the ${ }^{125}$ I organification activity of the control group remained at approximately $90 \%$ from $30 \mathrm{~min}$ to $24 \mathrm{hr}$ after administration in the control animals.

The activity of the KA group was significantly lower than control from 30 min to $6 \mathrm{hr}$ after administration. However, when $\mathrm{Na}{ }^{125} \mathrm{I}$ was given intraperitoneally at 24 or $48 \mathrm{hr}$ after administration of KA, the activity recovered enough to be nearly comparable with that of the control (Fig. 5).

\section{Serum T3, T4, and TSH concentrations}

As shown in Table 1, serum T3 showed a tendency to increase from $30 \mathrm{~min}$ to $6 \mathrm{hr}$ after administration of KA, while serum T4 showed a tendency to decrease from 2 to $48 \mathrm{hr}$ after administration. Serum TSH level did not fluctuate in evident association with

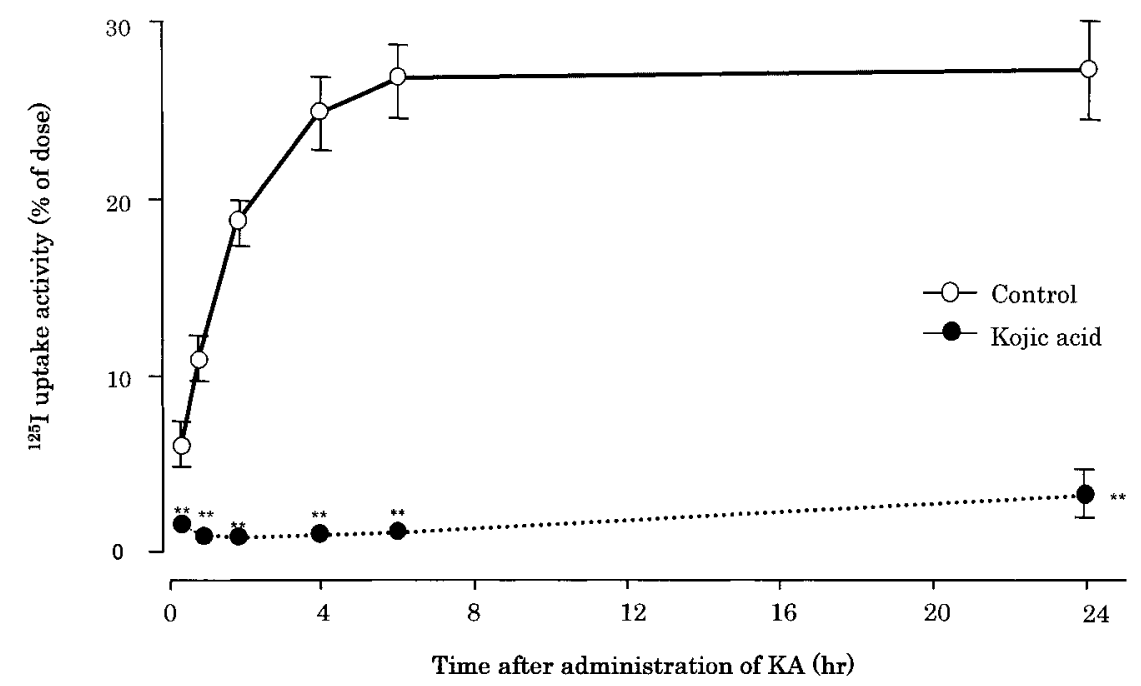

Fig. 2. ${ }^{125}$ I uptake activity in rat thyroid after single oral administration of $1000 \mathrm{mg} / \mathrm{kg} \mathrm{KA}$. $\mathrm{KA}$ and $\mathrm{Na}^{125} \mathrm{I}$ were administered simultaneously.

${ }^{125}$ I uptake activity $;{ }^{125} \mathrm{I}$ uptake ratio $=$ (radioactivity in the thyroid / radioactivity administered to the animal) $\times 100$.

Each point represents the mean \pm S.D. of four rats.

**: $\mathrm{p}<0.01$ (Significantly different from control by $t$-test). 
Effects of Kojic acid on thyroidal functions in rats.

KA administration.

\section{In vitro study with FRTL-5 cells}

With regard to ${ }^{125}$ I uptake and organification activities, the effects on ${ }^{125}$ I uptake activity by KA or sodium perchlorate in FRTL-5 cells are shown in Fig. 6. KA did not inhibit ${ }^{125}$ I uptake at a concentration range from $0.1 \mu \mathrm{M}$ to $300 \mu \mathrm{M}$, while the positive control, sodium perchlorate, inhibited ${ }^{125}$ I uptake dosedependently.

The effects on ${ }^{125}$ I organification activity by KA or methimazole in FRTL-5 cells are shown in Fig. 7. Both KA and the positive control, methimazole, inhibited ${ }^{125}$ I organification dose-dependently.

\section{DISCUSSION}

In our previous study of oral administration for 4 weeks, in which rats were given $0,4,15,62.5,250$ and $1,000 \mathrm{mg} / \mathrm{kg}$ of $\mathrm{KA}$, we reported that the weight increase in the thyroid gland and a morphological change, i.e., hypertrophy of the thyroid follicular epithelial cells, were observed in the group given 1,000 $\mathrm{mg} / \mathrm{kg}$ of KA (Higa et al., 2000). In addition, ${ }^{125} \mathrm{I}$ uptake from blood into the thyroid and the ${ }^{125} \mathrm{I}$ in the TCA-precipitate fraction in the thyroid were enhanced in those rats, while ${ }^{125}$ I organification activity did not change. As for the serum hormone determination, although serum T4 concentration decreased, TSH concentration did not change in the $1,000 \mathrm{mg} / \mathrm{kg} \mathrm{KA}$ group. These changes were not observed at less than $1,000 \mathrm{mg} / \mathrm{kg}$ of KA. Based on these observations, we have speculated that thyroid hypertrophy was due to a decreased concentration of blood $\mathrm{T} 4$ and compensatingly enhanced thyroid function, and that the enhanced ${ }^{125}$ I uptake into the thyroid and enhanced ${ }^{125} \mathrm{I}$ in the TCA-precipitate fraction in the thyroid were due to thyroid hypertrophy caused by repeatedly administered KA at a massive dose for a long period of time. However, the mechanism of decreased T4 concentration has yet to be clarified with the 4-week repeated administration method, because the influence of thyroid hypertrophy was too dominant.

We therefore focused on the time-course changes of iodine uptake into the thyroid, iodine organification in the thyroid and the concentration of serum T3, T4 and TSH

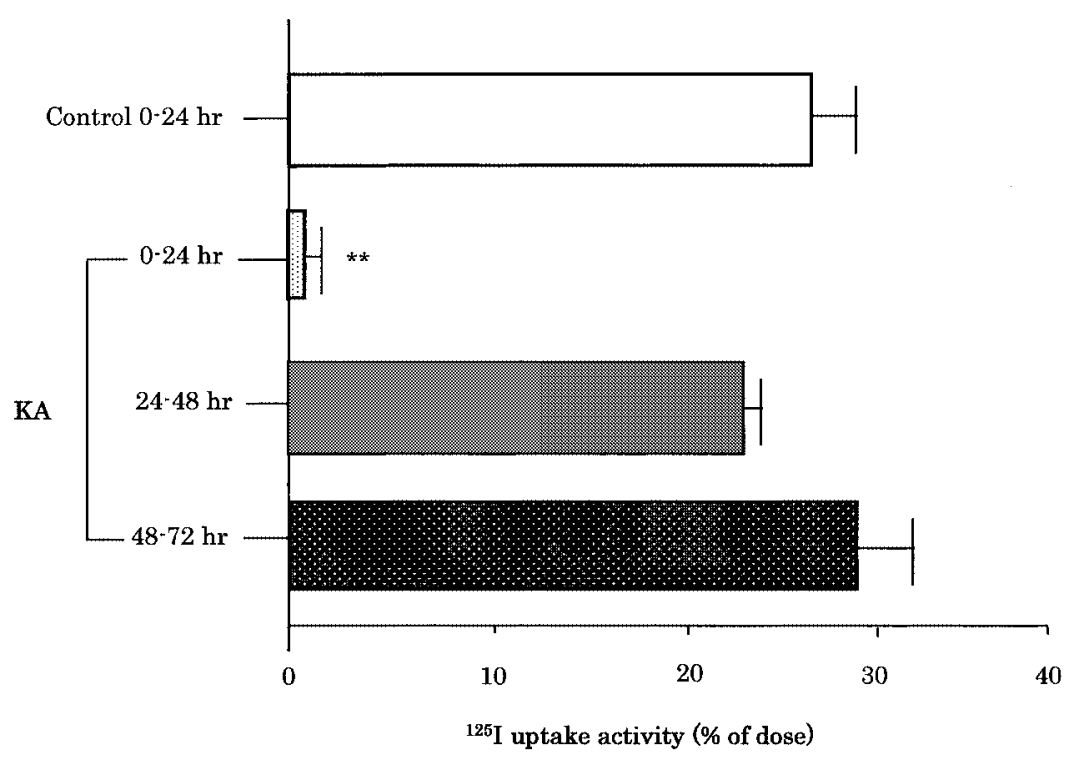

Fig. 3. ${ }^{125} \mathrm{I}$ uptake activity in rat thyroid for $24 \mathrm{hr}$ after intraperitoneal injection of $\mathrm{Na}^{125} \mathrm{I}$.

$\mathrm{Na}{ }^{125}$ I was injected intraperitoneally into rats at 0,24 or $48 \mathrm{hr}$ after single oral administration of $1000 \mathrm{mg} / \mathrm{kg} \mathrm{KA}$.

${ }^{125} \mathrm{I}$ uptake activity ; ${ }^{125} \mathrm{I}$ uptake ratio = (radioactivity in the thyroid / radioactivity administered to the animal) $\times 100$.

Each point represents the mean \pm S.D. of four rats.

$* * \mathrm{p}<0.01$ (Significantly different from control by $t$-test). 
caused by administration of KA in the present study. In addition, the effects of KA on iodine uptake into the thyroid and iodine organification in cultured rat thyroid cells (FRTL-5 cells) were also examined.

In the single-dose administration study in rats, the ${ }^{125}$ I uptake activity in the KA groups was significantly lower than that of the control group from $30 \mathrm{~min}$ to $24 \mathrm{hr}$ after administration (Fig. 2). The ${ }^{125} \mathrm{I}$ organification activity in the thyroid of the KA group was also significantly lower than control from $30 \mathrm{~min}$ to $6 \mathrm{hr}$ after administration. However, the figure recovered to be nearly comparable with the control at $24 \mathrm{hr}$ or $48 \mathrm{hr}$ after administration
(Fig. 4, 5). Based on these results, we assumed that the iodine organification ratio would recover more rapidly than the iodine uptake ratio.

The thyroid gland is comprised of thyroid epithelial cells and follicles, which are filled with colloid containing iodized thyroglobulin. The epithelial cells actively uptake iodine from the blood and organify the iodine on the colloid side of the epithelial cells or on the border. The organified iodine is then stored in the colloid (Imura, 1988; Daichi, 1995; Kloassen, 1996; Hardman and Limbird, 1996). From the results in FRTL-5 cells, namely that KA inhibited the iodine organification but did not inhibit

Table 1. Serum levels of T3,T4 and TSH in rats after single oral administration of $1000 \mathrm{mg} / \mathrm{kg} \mathrm{KA}$.

\begin{tabular}{|c|c|c|c|c|c|c|}
\hline \multirow[b]{2}{*}{ Time } & \multicolumn{2}{|c|}{ T3 (ng/dl ) } & \multicolumn{2}{|c|}{$\mathrm{T} 4(\mu \mathrm{g} / \mathrm{dl})$} & \multicolumn{2}{|c|}{ TSH (ng/ml) } \\
\hline & Control & $\mathrm{KA}$ & Control & $\mathrm{KA}$ & Control & $\mathrm{KA}$ \\
\hline $0.5 \mathrm{hr}$ & $220.5 \pm 25.3$ & $262.2 \pm 6.6^{*}$ & $6.0 \pm 0.3$ & $6.0 \pm 0.3$ & $4.0 \pm 6.0$ & $1.7 \pm 1.0$ \\
\hline $1 \mathrm{hr}$ & $236.5 \pm 24.3$ & $251.4 \pm 42.7$ & $6.4 \pm 0.4$ & $6.3 \pm 0.9$ & $4.9 \pm 5.3$ & $66.5 \pm 77.4$ \\
\hline $2 \mathrm{hr}$ & $249.5 \pm 27.4$ & $277.2 \pm 18.3$ & $7.6 \pm 0.3$ & $6.2 \pm 0.5^{* *}$ & $7.5 \pm 10.8$ & $21.3 \pm 40.8$ \\
\hline $4 \mathrm{hr}$ & $228.8 \pm 20.7$ & $312.1 \pm 21.5^{* *}$ & $6.6 \pm 0.3$ & $6.3 \pm 0.5$ & $2.2 \pm 1.7$ & $3.7 \pm 1.8$ \\
\hline $6 \mathrm{hr}$ & $196.0 \pm 16.0$ & $254.4 \pm 10.0^{* *}$ & $6.6 \pm 0.5$ & $5.7 \pm 0.7$ & $1.0 \pm 0.3$ & $2.1 \pm 0.8$ \\
\hline $24 \mathrm{hr}$ & $205.3 \pm 33.3$ & $201.4 \pm 26.9$ & $5.7 \pm 0.5$ & $4.7 \pm 0.4^{*}$ & $15.3 \pm 27.4$ & $2.4 \pm 1.4$ \\
\hline $48 \mathrm{hr}$ & $189.6 \pm 20.8$ & $198.9 \pm 21.9$ & $5.1 \pm 0.5$ & $4.7 \pm 0.3$ & $3.7 \pm 1.3$ & $2.5 \pm 1.2$ \\
\hline
\end{tabular}

Each value represents the mean \pm S.D. of four rats.

$*$ : $<<0.05,{ }^{*} \mathrm{p}<0.01$ ( Significantly different from control by $t$-test ).

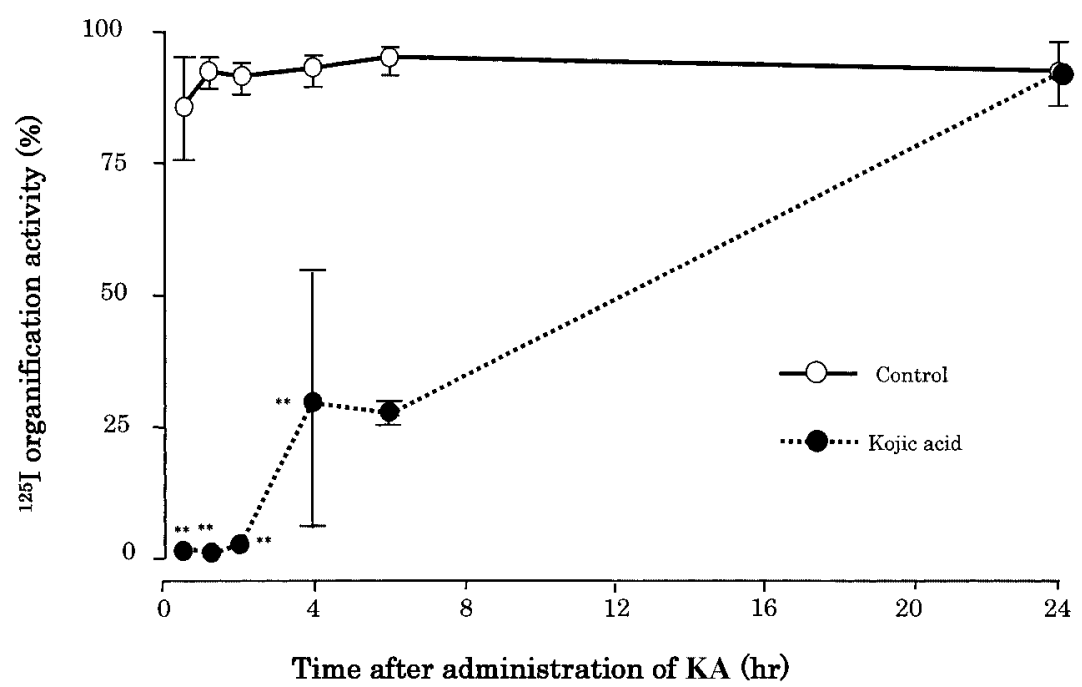

Fig. 4. ${ }^{125}$ I organification activity in rat thyroid after single oral administration of $1000 \mathrm{mg} / \mathrm{kg}$ KA.

$\mathrm{KA}$ and $\mathrm{Na}^{125} \mathrm{I}$ were administered simultaneously. ${ }^{125} \mathrm{I}$ organification activity ; ${ }^{125} \mathrm{I}$ organification ratio $=$ TPB (Thyroid Protein Binding $)=($ TCA precipitate radioactivity $/$ total radioactivity in the thyroid $) \times 100$.

Each point represents the mean \pm S.D. of four rats. $* *: p<0.01$ (Significantly different from control by $t$-test). 
Effects of Kojic acid on thyroidal functions in rats.

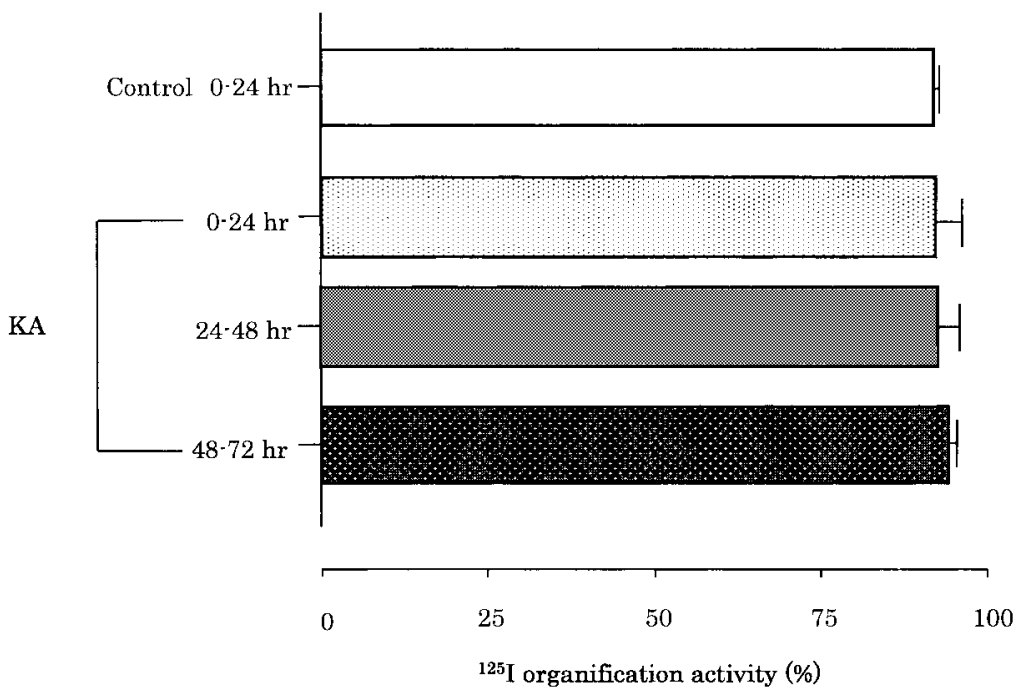

Fig. 5. ${ }^{125} \mathrm{I}$ organification activity in rat thyroid for $24 \mathrm{hr}$ after intraperitoneal injection of $\mathrm{Na}$ ${ }^{125} \mathrm{I}$.

$\mathrm{Na}{ }^{125} \mathrm{I}$ was injected intraperitoneally into rats at 0,24 or $48 \mathrm{hr}$ after single oral administration of $1000 \mathrm{mg} / \mathrm{kg} \mathrm{KA}$.

${ }^{125} \mathrm{I}$ organification activity $;{ }^{125} \mathrm{I}$ organification ratio $=$ TPB $($ Thyroid Protein Binding $)=$ (TCA precipitate radioactivity / total radioactivity in the thyroid) $\times 100$.

Each point represents the mean \pm S.D. of four rats.

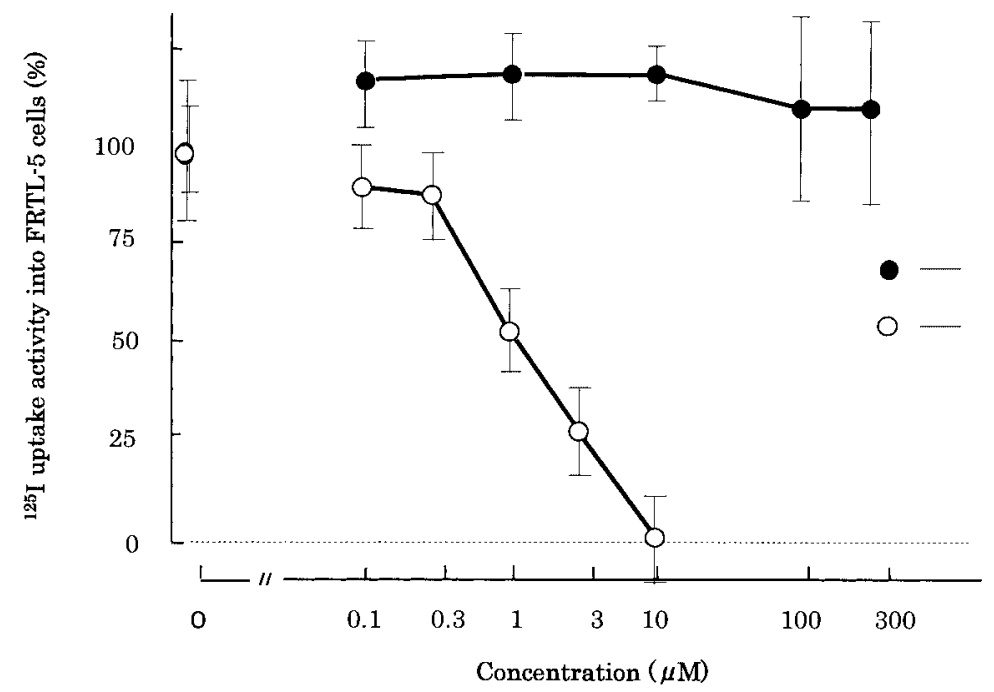

Fig. 6. Effects on ${ }^{125}$ I uptake activity by KA and Sodium perchlorate in FRTL-5 cells.

iodine uptake, it was presumed that the observed lower iodine uptake activity in the single-dose administration study in rats was due to decreased thyroglobulin in the colloid as a result of the inhibition of iodine organification caused by oral administration of KA, consequently decreasing iodine in the entire thyroid. Therefore, it is speculated that KA seemed to inhibit iodine uptake into the thyroid.

Although serum T4 showed a tendency to decrease from $2 \mathrm{hr}$ to $48 \mathrm{hr}$ after administration of KA, no evident changes in serum TSH suggested that single-dose administration of KA did not decrease serum $\mathrm{T} 4$ enough to 


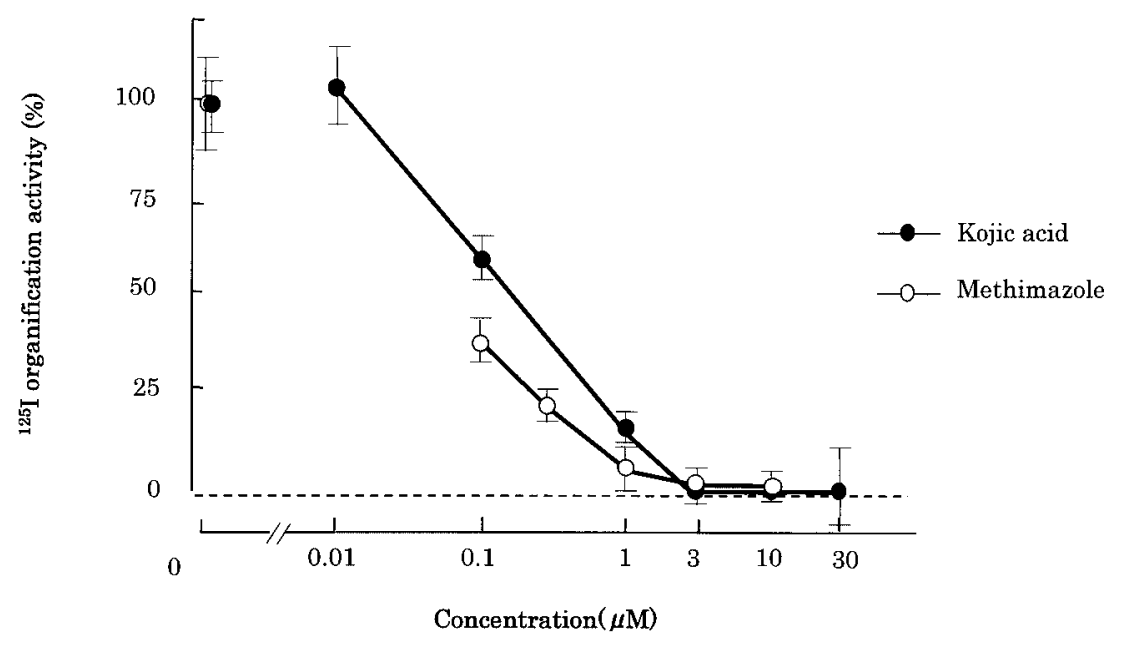

Fig. 7. Effects on ${ }^{125}$ I organification activity by KA and methimazole in FRTL-5 cells.

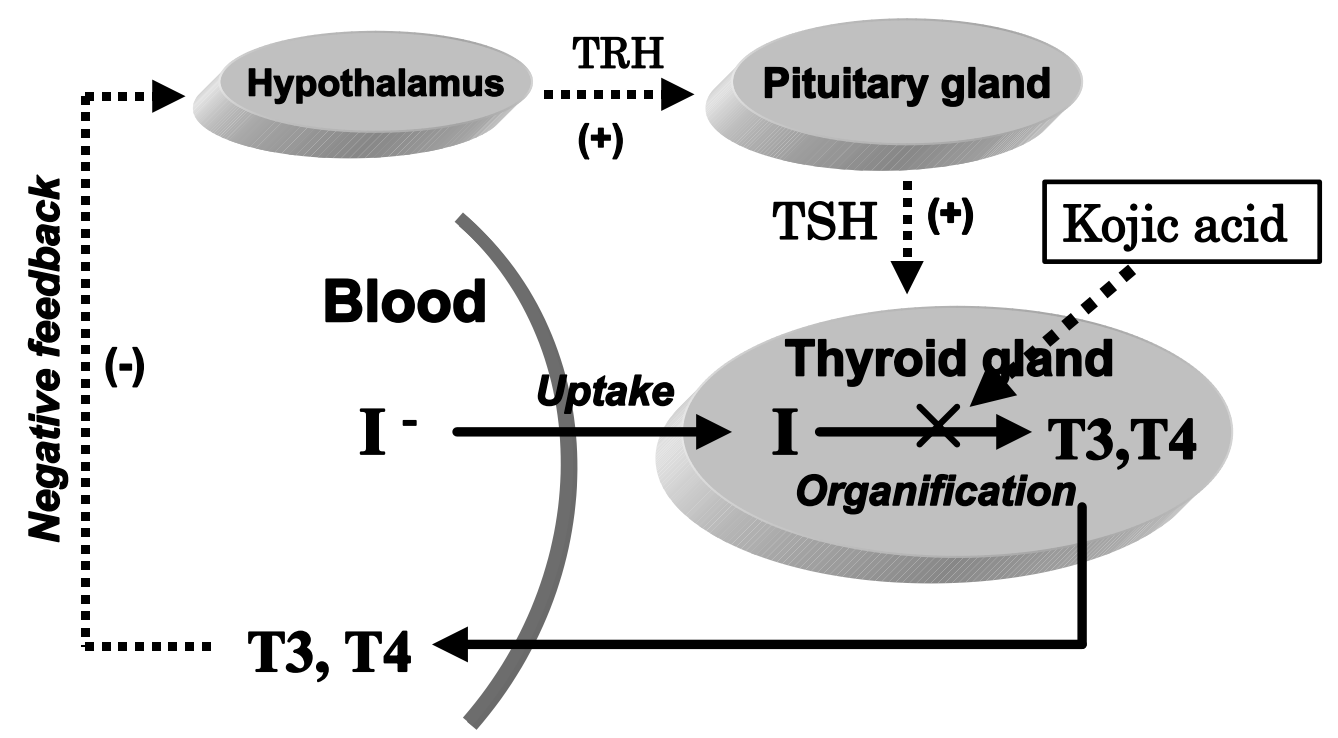

Fig. 8. Action mechanism of Kojic acid on rat thyroid function.

increase serum TSH. A massive dose or long administration period might be needed to decrease serum $\mathrm{T} 4$ and increase serum TSH.

Given the result that the decreased iodine uptake caused by KA was due to its inhibition of iodine organification, the action mechanism of KA on thyroidal function was considered as follows (Fig. 8): KA first inhibits iodine organification in the thyroid, and consequently the decreased iodized thyroglobulin in the colloids suppresses the formation of T3 and T4. This decreased blood T4 concentration leads to excessive TSH secretion through a negative feedback mechanism, and the thyroid gland is then enlarged. Although KA has been known to inhibit the activity of tyrosinase and restrain the biosynthesis of melanin (Nakayama, 1982; Higa, 1983), its effect on thyroid peroxidase activity has not yet been clarified.

Hirose et al. (2001) have reported that lack of DNA adducts and 8-OhdG formation in the thyroid of rats administered KA is not in accordance with genotoxic potential. Humans appear to be less sensitive to perturbation of the thyroid-pituitary status than rodents. In addition, it has been reported that monkeys are less sensitive to the goitrogenic effects of peroxi- 
Effects of Kojic acid on thyroidal functions in rats.

dase inhibitors such as phenyl thiourea and sulfamethoxazole, and there have been no reports of adverse effects on the thyroid after long-term clinical use of sulfonamides, suggesting that human risk of thyroid cancer due to such agents will be very low. In addition, Burdock et al. (2001) have concluded that KA consumed in an amount and in a manner consistent with historical use did not present a safety concern. Since KA is absorbed, metabolized and excreted rapidly, the function of iodine organification in rats recovers as rapidly as $24 \mathrm{hr}$ after KA administration. Therefore, the thyroid hypertrophy observed in rats is considered to be seen only when KA is given at a massive dose or for a long period of time.

\section{REFERENCES}

Ambesi-Impiombato, F.S., Parks, L.A.M. and Coon, H.G. (1980): Culture of hormone-dependent functional epithelial cells from rat thyroids. Proc. Natl. Acad. Sci., USA. , 77, 3455-3459.

Brown, C.G., Fowler, K.L., Nicholls, P.J. and Atterwill, Co. (1986): Assessment of thyrotoxicity using in vitro cell culture systems, Food Chem. Toxicol., 24, 557-562.

Burdock, G.A., Madhusudan, G.S. and Carabin, I.G. (2001): Evaluation of health aspects of Kojic Acid in Food, Reg. Toxicol. Pharmacol., 33, 80-101.

Chiovato, L., Martino, E., Tonacchera, M., Santini, F., Lapi, P., Mammolic, C., Bravenrman, L.E. and Pinchera, A. (1994): Studies on the in vitro cytotoxic effect of amiodarone, Endocrinology, 134, 227-282.

Daichi, M. (1995): Textbook of Physiology, 2nd Edition, Bunkodo.

Fujimoto, N., Onodera, H., Mitsumori, K., Tamura, T., Maruyama, S. and Ito, A. (1999): Changes in thyroid function during development of thyroid hyperplasia induced by kojic acid in F344 rats. Carcinogenesis vol.20 no.8 pp.1567-1571.

Hardman, J.G. and Limbird, L.E. (1996): Thyroid and antithyroid Drugs, Goodman and Gilman's Pharmacological Basis of Therapeutics-9th ed., McGraw-Hill.

Higa, Y. (1983): Inhibitory activity of Kojic Acid on the biosynthesis of melanin, Fragrance J., 63, 40-44.

Higa, Y., Ohkubo, A., Kitajima, S., Hatori, A. and Kariya, K. (2000): Studies on thyroid function in rats subjected to repeated oral administra- tion with kojic acid, J. Toxicol. Sci., 25, 167175.

Hirose, M., Nishikawa, A., Shibutani, M. and Mitsumori, K. (2001): Environmental agents, endocrine disrupting chemicals and rat thyroid carcinogenesis. J. Toxicol. Pathol., 14, 71-77.

Imura, H. (1988), Endocrinology, Capture 7: Thyroid Gland, Kinpodo, Kyoto.

Kloassen, C.D. (1996): Toxic response of the endocrine system, Casarett and Doull's ToxicologyThe Basic Science of Poisons-5th Ed., McGrawHill.

Lowry, O.H., Rosenbriough, N.J., Farr, A.L. and Randall, R.J. (1951): Protein measurement with the folin phenol reagent. J. Biol. Chem., 193, 265-275.

Nakayama, H., Watanabe, N., Nishioka, K., Hayakawa, R. and Higa, Y. (1982): Treatment of chloasma with topical Kojic Acid. Jap. J. Clin. Dermatol., 36, 715-722.

Ohyama, Y. and Mishima, Y. (1990): Function and Skin-Whitening effect of Kojic Acid, Fragrance Journal, 6, 53-58.

Stuart, J.W., Nancy, J.P. and Evelyn, F.G. (1984): Iodide transport in a continuous line of cultured cells from rat thyroid. Endocrinology, 114, 1090-1098.

Tamura, T., Mitsumori, K., Onodera, H., Fujimoto, N., Yasuhara, K., Takegawa, K. and Takahashi, M. (1999): Inhibition of thyroid iodine uptake and organification in rats treated with Kojic Acid. Toxicol. Sci., 47, 170-175.

Uchino, K. (1986a): Freshness-preserving agents for perishables and method of preservation, Japanese Patent, No. 198372/1987.

Uchino, K. (1986b): Decoloration prevention method for meats, Japanese patent, No. 224261/1987.

Valente, W.A., Vitti, P., Kohn, L.D., Brandi, M.L., Rotella, C.M., Toccafondi, R., Tramontano, D., Aloj, S.M. and Ambesi-Impiombato, F.S. (1983): The relationship of growth and adenylate cyclase activity in cultured thyroid cells: Separate bioeffects of thyrotropin. Endocrinology, 112, 71-79.

Weiss, S.J., Philp, N.J. and Grollman, E.F. (1984): Iodide transport in a continuous line of cultured cells from rat thyroid. Endocrinology, 114, 1090-1098.

Yoshimura, I. (1987): In "Statistical Analysis of Toxicological Data", pp. 28-37, 75-78, Scientist Inc., Tokyo (in Japanese). 